\title{
Borrelia Burgdorferi Antibody Measurement
}

National Cancer Institute

\section{Source}

National Cancer Institute. Borrelia Burgdorferi Antibody Measurement. NCI Thesaurus.

Code C122098.

The determination of the amount of Borrelia burg dorferi antibody present in a sample. 